\title{
Factors associated with poor outcome in tuberculous meningitis; study from a tertiary care referral Centre from South India
}

\author{
L Mathukumalli N. ${ }^{1 *}$, Reddy Kola S. ${ }^{2}$, A Kanikannan M. ${ }^{3}$, Turaga S. ${ }^{4}$, Borgohain R. ${ }^{5}$ \\ DOI: https://doi.org/10.17511/ijmrr.2021.i03.03 \\ 1* Neeharika L Mathukumalli, Assistant Professor, Department of Neurology, Nizam's Institute of Medical Sciences, Hyderabad, Telangana, \\ India. \\ 2 Sruthi Reddy Kola, Department of Neurology, Nizam's Institute of Medical Sciences, Hyderabad, Telangana, India. \\ 3 Meena A Kanikannan, Department of Neurology, Nizam's Institute of Medical Sciences, Hyderabad, Telangana, India. \\ ${ }^{4}$ Suryaprabha Turaga, Department of Neurology, Nizam's Institute of Medical Sciences, Hyderabad, Telangana, India. \\ 5 Rupam Borgohain, Department of Neurology, Nizam's Institute of Medical Sciences, Hyderabad, Telangana, India.
}

Introduction: Tuberculosis (TB) remains a worldwide burden with a large majority of new active cases occurring in underdeveloped and developing countries. This study is an attempt to look into various aspects of the disease that can be associated with the outcome, to promote a timely referral to an appropriate centre. Purpose: To identify various clinical, lab, CSF and radiological variables associated with poor outcome of TBM at the time of discharge. Material \& Methods: Demographic data, duration of symptoms before diagnosis, clinical presentation, staging of the disease at the time of admission of all the TBM patients who presented to our centre between December, 2015 and May 2018 were noted. Results of biochemical investigations and brain and spine imaging were retrieved. Outcome at the time of discharge as measured by MRC and mRS grades was correlated to clinical profile, lab, CSF and radiological findings. Results: A total of 100 patients were included. 15 patients died. Subjects with MRC and mRS grades of 2 or more at admission constituted $65 \%$ and $93 \%$ respectively. At discharge, MRC and mRS grades of 2 or more were found in $29.63 \%$ and $39 \%$ respectively. Multivariable analysis showed a significant positive association of MRC stage at discharge with MRC stage $(p=0.001)$ and mRS score $(p=0.001)$ at admission and Vellore hydrocephalus grade $(p<0.001)$ when hydrocephalus first identified. Conclusion: Stage of the disease (MRC) and functional status of the patient (mRS) at admission are the two most important independent factors determining the outcome of TBM patients at the time of discharge.

Keywords: Factors, Poor outcome, TBM, Tuberculous meningitis, Prognosis

\section{Corresponding Author}

Neeharika L Mathukumalli, Assistant Professor, Department of Neurology, Nizam's Institute of Medical Sciences, Hyderabad, Telangana, India. Email: drmineeharika@gmail.com

\section{How to Cite this Article}

Mathukumalli NL, Kola SR, Kanikannan MA, Turaga S, Borgohain R. Factors associated with poor outcome in tuberculous meningitis; study from a tertiary care referral Centre from South India. Pediatric Rev Int J Pediatr Res. 2021;9(3):146-153.

Available From

https://ijmrr.medresearch.in/index.php/ijmrr/article/ view/1126
To Browse

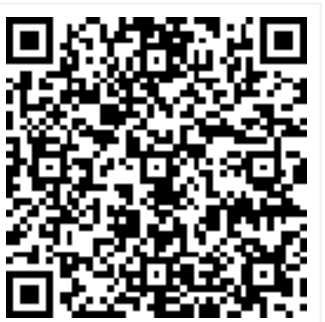

Manuscript Received 2021-05-06

Conflict of Interest No
Review Round 1 2021-05-16

Funding

$\mathrm{Nil}$

Review Round 2
2021-05-27
Ethical Approval
Yes

Review Round 3

Plagiarism X-checker $9 \%$
Accepted 2021-06-02

Note

(c) 2021 by Neeharika L Mathukumalli, Sruthi Reddy Kola, Meena A Kanikannan, Suryaprabha Turaga, Rupam Borgohain and Published by Siddharth Health Research and Social Welfare Society. This is an Open Access article licensed under a Creative Commons Attribution 4.0 International License https://creativecommons.org/licenses/by/4.0/ unported [CC BY 4.0]. 


\section{Introduction}

Tuberculosis (TB) remains a worldwide health concern with a large majority of new active cases occurring in underdeveloped and developing countries. WHO estimates that five countries India, China, South Africa, Indonesia and Pakistan account for greater than $70 \%$ of the global burden of the disease. [1]. Twenty-six per cent of these cases live in India. [2]. India accounts for nearly 2.5 million new infections annually leading to over 200,000 deaths. [3]. In 2016, the death toll in India due to TB was estimated at 4.5 lakh population with a total of 28 lakh new cases.

Tuberculous meningitis (TBM) constitutes approximately $1 \%$ of all cases of TB. [4]. Globally, the number of TBM cases would be over 100,000 annually. Despite a good clinical exposure in India, diagnosis of TBM remains a challenge as it is a great mimicker of various other diseases with its wide spectrum of manifestations. Due to heterogeneity of the disease, reliance on microbiological confirmation often results in misdiagnosis or a delay in diagnosis and initiation of therapy. India has more than a million "missing" cases every year that are not notified.

TBM has higher morbidity and mortality than any other form of TB with a reported incidence of mortality $>20 \%$ and neurological sequelae in $78.5 \%$ of patients. [5]. Delay in diagnosis and treatment is one of the major factors contributing to morbidity and mortality. [6]. With poor availability of resources for diagnosis and treatment in the rural and suburban population who form the major chunk of cases, mortality due to TBM in India remained high i.e. 1.5/100000. [7]. Fatalities are also caused by disease complications and the inability to detect antimicrobial resistance.

Additionally, there is a real risk that the increasing incidence of MDR-TB and even XDR-TB can lead to increased disease burden as well as deaths. Lack of expertise at peripheral health care in dealing with the disease complications and delay in referring cases to a tertiary care centre is leading to significant morbidity. The drug in compliance due to financial constraints is one of the major factors contributing to indolently spreading multidrug resistance amongst Mycobacteria, adding to the complex scenario. This study is an attempt to look into various aspects of the disease that can predict the outcome, to promote a timely referral to an appropriate centre thus lessening the case fatalities.
And also, all the previously published studies explored various parameters that influence the final clinical outcome, taking the Modified Research Council (MRC) stage of the disease as their primary outcome variable. $[5,6,8,9]$. Kalita et al and Van Well et al in their analysis included neurologic sequelae as one of the primary outcome variables. No series addressed the need for analyzing the factors determining functional independence in patients of TBM. In our series, we assessed the impact of various aspects of the disease predicting the clinical and functional outcome of TBM at the time of discharge.

Aim: To identify various clinical, CSF and radiological variables predicting the outcome of TBM at the time of discharge.

\section{Materials and methods}

Study type: a retrospective observational study

Study duration: 2.5 years

Inclusion criteria: All patients of TBM as defined by Thwaites criteria [8]. admitted to Nizam's Institute of Medical Sciences, Hyderabad, India from December 2015 to May 2018 were included in the study.

Exclusion criteria: Pregnant women, HIV positive subjects and subjects diagnosed with other causes of meningitis were excluded.

Approval of the Institutional ethics committee was obtained.

Data collection and analysis: Demographic data, duration of symptoms before diagnosis, duration of hospital stay, clinical presentation, clinical staging of the disease as per MRC stage, disability scoring by Modified Rankin scale (mRS) at the time of admission and discharge were noted. Data including routine blood investigations, chest X-ray, cerebrospinal fluid (CSF) analysis and brain and/ or spine imaging (MRI including post-contrast images $\pm \mathrm{CT}$ ) were retrieved. Complications during hospital stay like the development of hydrocephalus, pneumonia, sepsis and drug-induced hepatitis were noted.

Hydrocephalus is confirmed when Evan's index $\geq$ 0.3 , which is a linear ratio of the maximum width of the frontal horns of the lateral ventricles and maximal internal diameter of the skull at the same level in axial CT or MRI images. Hydrocephalus was graded as per modified Vellore grading. 
Subsequent MRI or CT imaging during follow up was done only in subjects suspected to have developed complications like hydrocephalus, paradoxical reaction, optochiasmatic arachnoiditis and vasculitis.

All patients were treated with four-drug regimen of isoniazid $5 \mathrm{mg} / \mathrm{kg} /$ day (maximum of $300 \mathrm{mg} /$ day); rifampicin $10 \mathrm{mg} / \mathrm{kg} /$ day (maximum of $600 \mathrm{mg} /$ day) for 12 months supplemented by pyrazinamide 15-30 $\mathrm{mg} / \mathrm{kg} /$ day (maximum of $2000 \mathrm{mg} /$ day) and streptomycin $20-40 \mathrm{mg} / \mathrm{kg} /$ day or ethambutol $15-25$ $\mathrm{mg} / \mathrm{kg} /$ day for the first 2 months. All patients with stage 2 or 3 MRC received dexamethasone 8 - 16 $\mathrm{mg} /$ day for 3 - 6 weeks, tapered over the next 2 4 weeks. Patients with hydrocephalus and altered sensorium and/ or neurological deficit underwent ventriculoperitoneal shunting unless CSF protein was more than $1 \mathrm{~g} / \mathrm{l}$. In the latter case, a temporary external ventricular drainage using a reservoir was kept.

Poor clinical outcome is defined as death, MRC stage $\geq$ II and poor functional outcome as mRS score $\geq 2$ at the time of discharge. These variables were correlated to clinical profile (presence of seizures, focal limb weakness, cranial nerve palsies, altered sensorium, MRC stage, mRS score and Vellore grade at presentation, occurrence of ventilator-associated pneumonia or pneumonia complicating aspiration and or sepsis during hospital stay), lab parameters (hyponatremia, drug-induced hepatitis), CSF (opening pressure, protein, glucose, total leucocyte count) and radiological findings (presence of basal meningeal enhancement, hydrocephalus and vasculitis).

Statistical methods: MRC stage and mRS score at discharge was considered as primary outcome variables. Various clinical, CSF and imaging features, MRC stage and mRS score at admission were considered as primary explanatory variables. Descriptive analysis was carried out by mean and standard deviation for quantitative variables, frequency and proportion for categorical variables. The association between primary explanatory variables and primary outcome variables were assessed by cross-tabulation and comparison of percentages. The Chi-square test was used to test statistical significance. Variables with a probable association with MRC stage and mRS score at discharge on univariate analysis were included in a multivariable logistic regression model to accurately identify an independent association. P-value $<0.05$ was considered statistically significant. IBM SPSS version 22 was used for statistical analysis. [10].

\section{Results}

A total of 100 patients were included, 5 of them were probable TBM and the remaining were possible TBM. The median age was 29 (range $9-63$ years). Of them, $41 \% \quad(n=41)$ were male. The median duration of symptoms to diagnosis was 20 days (range $4-40$ days). The median time taken for the patients to arrive at our hospital was 6 days for those with MRC stage I, 12 days for those with MRC stage II and 4 days for those with MRC stage III. The duration of hospital stay ranged from 7 to 30 days (median of 15 days). The most common symptoms were fever (71\%), headache (71\%), altered sensorium (47\%) followed by weight loss and vomiting (38\%). (Table 1 )

Table-1: Clinical profile of patients $(n=100)$

\begin{tabular}{|l|l|l|}
\hline \multicolumn{1}{|c|}{ Symptom } & Frequency & \multicolumn{1}{c|}{ Percentages } \\
\hline Headache & 71 & $71 \%$ \\
\hline Fever & 71 & $71 \%$ \\
\hline Vomiting & 38 & $38 \%$ \\
\hline Anorexia & 14 & $14 \%$ \\
\hline Night sweats & 8 & $8 \%$ \\
\hline Weight loss & 38 & $38 \%$ \\
\hline Seizures & 28 & $28 \%$ \\
\hline Focal limb weakness & 30 & $30 \%$ \\
\hline Visual field defects & 16 & $16 \%$ \\
\hline Altered sensorium & 47 & $47 \%$ \\
\hline Cranial nerve palsy & 26 & $26 \%$ \\
\hline
\end{tabular}

CSF leucocytosis (lymphocyte predominating) was seen in $82 \%(n=82)$ and mean leucocyte count was $87.55 \pm 18.15 /$ ul. The mean CSF glucose and protein levels were $32 \pm 6 \mathrm{mg} / \mathrm{dl}$ and $74 \pm 3 \mathrm{mg} / \mathrm{dl}$ respectively. CSF showed elevated protein in $75 \%$ $(n=75)$, and low glucose in $39 \%(n=39)$. CSF gene Xpert for TB was positive in $60 \%(n=60)$. (Table 2 )

Table 2: Findings of CSF analysis

\begin{tabular}{|c|c|c|}
\hline CSF & Frequency & Percentages \\
\hline \multicolumn{3}{|l|}{ Cells } \\
\hline Normal & 17 & $17 \%$ \\
\hline Leucocytosis & 83 & $82 \%$ \\
\hline \multicolumn{3}{|l|}{ Protein } \\
\hline Normal & 25 & $25 \%$ \\
\hline Increased & 75 & $75 \%$ \\
\hline \multicolumn{3}{|l|}{ Glucose } \\
\hline Normal & 61 & $61 \%$ \\
\hline Decreased & 39 & $39 \%$ \\
\hline \multicolumn{3}{|l|}{ Pressure } \\
\hline Normal & 73 & $73 \%$ \\
\hline Elevated & 27 & $27 \%$ \\
\hline
\end{tabular}


Mathukumalli NL. et al: Factors associated with poor outcome in tuberculous

\begin{tabular}{|l|l|l|}
\hline Gene Xpert & 60 & $60.00 \%$ \\
\hline Positive & 40 & $40.00 \%$ \\
\hline Negative & $87.55 \pm 18.15 / \mathrm{ul}$ \\
\hline Mean CSF leucocyte count & $32 \pm 6 \mathrm{mg} / \mathrm{dl}$ \\
\hline Mean CSF glucose & $74 \pm 3 \mathrm{mg} / \mathrm{dl}$ \\
\hline Mean CSF protein & \\
\hline
\end{tabular}

Imaging revealed intracranial meningeal enhancement in $95 \%(n=95)$, of which meningeal enhancement across Sylvian fissure is seen in $8 \%$ $(n=8)$, basal exudates were seen in $42 \%(n=42)$. Concomitant spinal arachnoiditis was found in $8 \%$ $(n=8)$, vasculitic infarcts in $28 \% \quad(n=28)$, tuberculoma in $40 \% \quad(n=40)$. (Table 3) Twenty patients had hydrocephalus at the time of admission, 32 patients had hydrocephalus during the hospital stay, 11 patients developed hydrocephalus after discharge within the first month of illness. $37 \% \quad(n=37)$ patients underwent ventriculoperitoneal shunting and $7 \% \quad(n=7)$ underwent reservoir placement with external ventricular drainage. Drug-induced hepatitis occurred in $34 \%(n=34)$ of the patients.

\section{Table 3: Brain and spine imaging findings}

\begin{tabular}{|c|c|c|}
\hline Imaging finding & Frequency & Percent \\
\hline Meningeal Enhancement & 95 & $95 \%$ \\
\hline Diffuse & 29 & $29 \%$ \\
\hline Across sylvian fissure & 8 & $8 \%$ \\
\hline Frontal & 5 & $5 \%$ \\
\hline Temporal & 8 & $8 \%$ \\
\hline Parietal & 10 & $10 \%$ \\
\hline Occipital & 4 & $4 \%$ \\
\hline Cerebellar & 2 & $2 \%$ \\
\hline Basal & 42 & $42 \%$ \\
\hline Hydrocephalus & 63 & $63 \%$ \\
\hline Communicating & 45 & $45 \%$ \\
\hline Non communicating & 18 & $18 \%$ \\
\hline Vasculitis infarcts & 28 & $28 \%$ \\
\hline Brainstem & 5 & $5 \%$ \\
\hline Capsuloganglionic & 9 & $9 \%$ \\
\hline ACA territory & 1 & $1 \%$ \\
\hline MCA territory & 5 & $5 \%$ \\
\hline PCA territory & 3 & $3 \%$ \\
\hline Multiple subcortical & 3 & $4 \%$ \\
\hline Thalamus & 2 & $2 \%$ \\
\hline \multicolumn{3}{|l|}{ Other features in brain imaging } \\
\hline Abscess & 2 & $2 \%$ \\
\hline Brain Tuberculoma & 40 & $40 \%$ \\
\hline Optochiasmatic arachnoiditis & 8 & $8 \%$ \\
\hline Choroid plexitis & 6 & $6 \%$ \\
\hline \multicolumn{3}{|l|}{ Spine imaging } \\
\hline Arachnoiditis & 8 & $8 \%$ \\
\hline
\end{tabular}

\begin{tabular}{|l|l|l|}
\hline Intramedullary tuberculoma & 3 & $3 \%$ \\
\hline Potts's spine & 1 & $1 \%$ \\
\hline
\end{tabular}

At admission, 35\% $(n=35)$ patients had stage I disease, $53 \%(n=53)$ had stage II disease and $12 \%$ $(n=12)$ had stage III disease. MRC stage II or more and mRS score of 2 or more was found in $65 \%$ $(n=65)$ and $93 \%(n=93)$ respectively at the time of admission, and Vellore grade for hydrocephalus of 3 or more in $55 \%(n=55)$ when hydrocephalus first identified. 15 patients died during a hospital stay. Amongst the rest, $71.8 \%(n=61)$ of patients were in MRC stage I, 15.3\% $(n=13)$ in MRC stage II and $12.9 \%(n=11)$ in MRC stage III at discharge. Poor outcome i.e., MRC stage II or more and mRS score 2 or more was found in $29.63 \%(n=24)$ and $39 \%$ $(n=39)$ respectively.

On univariate analysis, MRC stage at discharge correlated with altered sensorium at presentation $(p<0.001)$, elevated CSF opening pressure $(p=0.015)$, presence of vasculitis on MRI $(p=0.017), M R C$ stage $(p<0.001)$, mRS score $(p=0.01)$ at admission and Vellore hydrocephalus grade $(p<0.001)$. Presence of these clinical, CSF and radiological features, higher MRC stage, higher mRS score, higher Vellore hydrocephalus grade correlated with poor clinical outcome. (Table 4)

Table 4: Factors associated with MRC stage at discharge (Univariate analysis)

\begin{tabular}{|c|c|c|c|c|}
\hline \multirow[t]{2}{*}{ Factor } & \multicolumn{2}{|c|}{ MRC stage at discharge } & \multirow[t]{2}{*}{ Chi-square } & \multirow[t]{2}{*}{ P-value } \\
\hline & $\begin{array}{l}\text { Good outcome } \\
(M R C<2)\end{array}$ & $\begin{array}{l}\text { Poor outcome } \\
(M R C \geq 2)\end{array}$ & & \\
\hline \multicolumn{5}{|l|}{ Altered sensorium } \\
\hline Yes $(n=47)$ & $24(51 \%)$ & $23(49 \%)$ & \multirow[t]{2}{*}{12.14} & \multirow[t]{2}{*}{$<0.001$} \\
\hline No $(n=53)$ & $46(86.7 \%)$ & $7(13.3 \%)$ & & \\
\hline \multicolumn{5}{|l|}{ CSF Pressure } \\
\hline Normal $(n=73)$ & $57(78 \%)$ & $16(22 \%)$ & \multirow[t]{2}{*}{5.972} & \multirow[t]{2}{*}{0.015} \\
\hline Elevated $(n=27)$ & $14(51.6 \%)$ & $13(48.4 \%)$ & & \\
\hline \multicolumn{5}{|l|}{ Vasculitic infarcts } \\
\hline Present $(n=28)$ & $13(46.4 \%)$ & $15(53.6 \%)$ & \multirow[t]{2}{*}{5.662} & \multirow[t]{2}{*}{0.017} \\
\hline Absent $(n=72)$ & $55(76.4 \%)$ & $17(23.6 \%)$ & & \\
\hline \multicolumn{5}{|c|}{ MRC stage at admission (analyzed for 85 subjects) } \\
\hline I & $31(50.8 \%)$ & $4(16.7 \%)$ & \multirow[t]{4}{*}{16.019} & \multirow[t]{4}{*}{$<0.001$} \\
\hline II & $30(49.2 \%)$ & $16(66.7 \%)$ & & \\
\hline III & 0 & $4(16.7 \%)$ & & \\
\hline Total & $61(100 \%)$ & $24(100 \%)$ & & \\
\hline \multicolumn{5}{|c|}{ mRS score at admission } \\
\hline 1 & $7(11.5 \%)$ & 0 & \multirow[t]{5}{*}{13.299} & \multirow[t]{5}{*}{0.01} \\
\hline 2 & $27(44.3 \%)$ & $5(12.8 \%)$ & & \\
\hline 3 & $16(26.2 \%)$ & $9(23 \%)$ & & \\
\hline 4 & $10(16.4 \%)$ & $6(15.4 \%)$ & & \\
\hline 5 & $1(1.6 \%)$ & $4(10.3 \%)$ & & \\
\hline
\end{tabular}




\begin{tabular}{|c|c|c|c|c|}
\hline 6 & 0 & $15(38.5 \%)$ & & \\
\hline Total & $61(100 \%)$ & $39(100 \%)$ & & \\
\hline \multicolumn{5}{|c|}{ Vellore grade for hydrocephalus $(n=63)$} \\
\hline 1 & $6(21.4 \%)$ & 0 & \multirow[t]{5}{*}{18.707} & \multirow[t]{5}{*}{$<0.00$} \\
\hline 2 & $1(3.6 \%)$ & $1(2.9 \%)$ & & \\
\hline 3 & $21(75 \%)$ & $20(57.1 \%)$ & & \\
\hline 4 & 0 & $14(40 \%)$ & & \\
\hline Total & $28(100 \%)$ & $35(100 \%)$ & & \\
\hline
\end{tabular}

Functional independence at discharge (as determined by mRS score), on univariate analysis, correlated negatively with focal limb weakness $(p=0.004)$, altered sensorium $(p=0.01)$ at presentation, elevated CSF protein $(p=0.009)$, higher MRC stage $(p<0.001)$, higher mRS score $(p<0.001)$ and higher Vellore hydrocephalus grade $(p<0.001)$. (Table 5) Time to diagnosis correlated neither with poor clinical nor functional outcome.

\section{Table 5: Factors associated with mRS score at} discharge (Univariate analysis)

\begin{tabular}{|c|c|c|c|c|}
\hline \multirow[t]{2}{*}{ Factor } & \multicolumn{2}{|c|}{ mRS score at discharge } & \multirow[t]{2}{*}{ Chi-square } & \multirow[t]{2}{*}{ P-value } \\
\hline & $\begin{array}{l}\text { Good outcome } \\
(m R S<2)\end{array}$ & $\begin{array}{l}\text { Poor outcome } \\
(m R S>2)\end{array}$ & & \\
\hline \multicolumn{5}{|c|}{ Focal limb weakness } \\
\hline Present $(n=30)$ & $14(46.7 \%)$ & $16(53.3 \%)$ & \multirow[t]{2}{*}{8.525} & \multirow[t]{2}{*}{0.004} \\
\hline Absent $(n=70)$ & $53(75.7 \%)$ & $17(24.3 \%)$ & & \\
\hline \multicolumn{5}{|l|}{ Altered sensorium } \\
\hline Yes $(n=47)$ & $24(51.1 \%)$ & $23(48.9 \%)$ & \multirow[t]{2}{*}{6.580} & \multirow[t]{2}{*}{0.010} \\
\hline No $(n=53)$ & $41(77.4 \%)$ & $12(22.6 \%)$ & & \\
\hline \multicolumn{5}{|l|}{ CSF protein } \\
\hline Normal $(n=25)$ & $22(88 \%)$ & $3(12 \%)$ & \multirow[t]{2}{*}{6.924} & \multirow[t]{2}{*}{0.009} \\
\hline Increase $(n=75)$ & $45(60 \%)$ & $30(40 \%)$ & & \\
\hline \multicolumn{5}{|c|}{ MRC stage at admission (analyzed for 85 subjects) } \\
\hline $\mathrm{I}$ & $21(77.8 \%)$ & $14(24.1 \%)$ & \multirow[t]{4}{*}{22.174} & \multirow[t]{4}{*}{$<0.001$} \\
\hline II & $6(22.2 \%)$ & $40(69.0 \%)$ & & \\
\hline III & 0 & $4(6.9 \%)$ & & \\
\hline Total & $27(100 \%)$ & $58(100 \%)$ & & \\
\hline \multicolumn{5}{|c|}{ mRS score at admission } \\
\hline 1 & $7(18.9 \%)$ & 0 & \multirow[t]{6}{*}{32.589} & \multirow[t]{6}{*}{$<0.001$} \\
\hline 2 & $16(43.3 \%)$ & $16(25.4 \%)$ & & \\
\hline 3 & $7(18.9 \%)$ & $18(28.6 \%)$ & & \\
\hline 4 & $6(16.2 \%)$ & $10(15.9 \%)$ & & \\
\hline 5 & $1(2.7 \%)$ & $4(6.3 \%)$ & & \\
\hline 6 & 0 & $15(23.8 \%)$ & & \\
\hline Total & $37(100 \%)$ & $63(100 \%)$ & & \\
\hline \multicolumn{5}{|c|}{ Vellore grade for hydrocephalus } \\
\hline 1 & $3(13.7 \%)$ & 0 & \multirow[t]{5}{*}{36.416} & \multirow[t]{5}{*}{$<0.001$} \\
\hline 2 & $5(22.7 \%)$ & 0 & & \\
\hline 3 & $14(63.6 \%)$ & $38(92.7 \%)$ & & \\
\hline 4 & 0 & $3(7.3 \%)$ & & \\
\hline Total & $22(100 \%)$ & $41(100 \%)$ & & \\
\hline
\end{tabular}

On further examination by multivariable analysis, a significant positive association was obtained with MRC stage $(p=0.001), m R S$ score $(p=0.001)$ at admission and Vellore hydrocephalus grade ( $p<$ 0.001 ) for MRC stage at discharge. mRS score at discharge had an independent positive association with MRC stage $(p<0.001)$ and mRS score $(p=0.002)$ at admission. (Table 6$)$

Table 6: Variables independently associated with poor outcome at discharge (Multivariate analysis)

\begin{tabular}{|c|c|c|c|}
\hline \multicolumn{4}{|c|}{ Variables associated with MRC stage $\geq$ II } \\
\hline & OR value & $95 \%$ CI & $\mathrm{P}$ value \\
\hline MRC at admission & 0.254 & $0.762-0.255$ & 0.001 \\
\hline mRS at admission & 0.467 & $1.317-1.383$ & 0.001 \\
\hline Vellore hydrocephalus grade & 0.369 & $1.162-1.424$ & 0.00005 \\
\hline \multicolumn{4}{|c|}{ Variables associated with $\mathrm{mRS}$ score $\geq 2$} \\
\hline & OR value & $95 \%$ CI & P value \\
\hline MRC at admission & 0.243 & $0.733-0.248$ & 0.00002 \\
\hline mRS at admission & 0.396 & $1.652-1.861$ & 0.002 \\
\hline Vellore hydrocephalus grade & 0.358 & $1.073-1.358$ & 0.612 \\
\hline
\end{tabular}

\section{Discussion}

CNS tuberculosis is one of the most devastating manifestations of infection with Mycobacterium tuberculosis. CNS TB can present as meningitis, tuberculoma, access or others. [11]. TBM accounts for $5 \%$ of all cases of extrapulmonary TB. [11]. Evidence of pulmonary TB is seen in around $50 \%$ of cases of TBM. $[12,13]$. TBM occurs when subpial or subependymal tubercles seeded during dissemination, the so-called Rich foci, rupture into subarachnoid space. [14]. In our series, a total of 100 patients were identified to have TBM. Most of them aged less than 30 years, constituting 56.5\%, which is following the previous reports. $[5,13]$.

The median duration of symptoms to diagnosis is 20 days (ranged from 4 - 40 days) suggesting a significant delay in referral from peripheral health care. Delay in diagnosis further impedes prompt initiation of treatment, which in itself is a poor prognostic factor for TBM. [15]. Hence, any patient hailing from an endemic area for TB, with fever and headache for more than 14 days is to be evaluated for TBM. [16]. However, in our series, subjects with MRC stage III disease presented very early in the course of the disease because of the ominous signs they had. Probably, specific immunological factors inherent to these patients played a major role in determining the fulminant course of the disease. 
In our series, $78 \%$ of patients had subacute presentation i.e they presented in the 3rd and 4th week of their illness. $22 \%$ of our patient population presented to the hospital within the first 2 weeks of the onset of symptoms. Though TBM classically follows a subacute disease course, acute presentations of TBM as high as $46.6 \%$ are well known. [17]. Six of our acute TBM patients were initially misdiagnosed as cerebral malaria or viral meningoencephalitis because of paucicellular CSF with normal or mildly elevated protein, normal glucose levels, normal plain and contrast MRI. Two of them were diagnosed as bacterial meningitis as CSF showed neutrophilic leukocytosis, hypoglycorrhachia and convexal meningeal enhancement before the diagnosis of TBM was made. All these cases were identified as TBM when MRI including post gadolinium sections were repeated because of drop-in sensorium after initiation of treatment.

The most common symptoms of TB meningitis are fever, headache, vomiting and altered level of consciousness. [18]. As is expected, the most common symptoms seen in our study population were fever $(71 \%)$ \& headache $(71 \%)$. Among the various clinical factors assessed, altered sensorium at presentation significantly correlated with MRC stage $(P<0.001)$ at discharge. This conforms with the previous reports. $[4,19,20]$. Forty-seven per cent of our patients had an altered level of consciousness on arrival. The altered sensorium in TBM is due to adjacent encephalon involvement, multiple tuberculomas with perilesional edema or single tuberculoma in a strategic location, vasculitis leading to infarction and hydrocephalus. [21].

Other factors associated with poor clinical outcome at discharge on univariate analysis, as defined by MRC stage $\geq$ II were elevated CSF opening pressure, presence of vasculitic infarcts on MRI, MRC stage, mRS score at admission and Vellore hydrocephalus grade. Cerebral infarction was an important predictor of the outcome at 6 and 12 months in a study conducted by Kalita et al. [19]. Infarction in TBM is a common complication that occurs due to thrombosis and strangulation of the vessels by the exudates. [19].

Vasculitic infarcts in TBM are commonly seen in the head of the caudate nucleus, genu and anterior limb of the internal capsule, and anteromedial thalamus, the so-called TB zone. [22]. Twenty-eight patients in our series had vasculitic infarction.
The commonest sites of infarction were the capsuloganglionic region $(n=9)$, brainstem $(n=5)$ and complete MCA territory $(n=5)$.

TBM is a disease with frequent neurological sequelae and fatalities if not treated early. $[12,13,23,24,25]$. Various case series indicate a mortality rate of $7 \%-65 \%$ in developed countries, and up to $69 \%$ in underdeveloped areas [23,24, 25 ]. Our mortality rate was $15 \%$. Major contributors for mortality in our subjects were pneumonia and sepsis owing to prolonged ICU stay, prolonged ventilatory support and surgical intervention. Vasculitis resulting especially in brainstem infarction also contributed to mortality.

Residual deficits are known to occur in as high as $50 \%$ of the survivors. [25]. On univariate analysis, the functional outcome at discharge as determined by $\mathrm{mRS}$ score is related to focal limb weakness, altered sensorium at presentation, elevated CSF protein, MRC stage, mRS score at admission and Vellore hydrocephalus grade. Focal limb weakness in TBM is attributed to vasculitic infarction, tuberculoma in strategic location or arachnoiditis. Thirty of our patients had focal limb weakness at the time of admission.

After multivariable analysis, the best set of predictors for clinical and functional outcome of TBM patients in our series at the time of discharge were MRC stage and mRS score at admission. Our results were similar to few other series published previously i.e., MRC grade at admission is one of the strong independent predictors of clinical outcome. $[5,6,8$, $9,26]$. This study addressed the outcome at the time of discharge. The outcome of TBM patients may get altered because of the complications that develop in the first 2 months of illness. Ideally, all these cases are to be followed for at least 2 months before concluding. As most of our complicated cases were discharged after a prolonged hospital stay of one month, we assume that outcome at discharge provides a valuable yardstick to assess treatment response.

\section{Conclusion}

Stage of the disease (MRC) and functional status of the patient (mRS) at admission are the two most important independent factors determining the outcome at the time of discharge in TBM. A high index of suspicion, early diagnosis and prompt treatment are highly essential in the management of TBM to reduce morbidity and mortality. 


\section{What does the study add to the existing knowledge?}

The present study highlights the importance of early diagnosis of TBM and prompt initiation of appropriate treatment. In an endemic country like India, any patient presenting with fever and headache for more than 2 weeks is to be suspected of having TBM. Acute presentations with noncontributory CSF and radiology are very much known with TBM. In those patients who present acutely and in those deteriorating while on treatment, daily clinical assessment and repeat radiological evaluation are warranted to come up with the correct diagnosis.

\section{Author's contribution}

All the authors participated actively during the whole study. All the authors reached out to each other in many ways like study design, data collection, and manuscript preparation.

\section{Reference}

01. Van TT, Farrar J. Tuberculous meningitis. J Epidemiol Community Health. 2014 Mar;68(3)1956. doi: 10.1136/jech-2013-202525 [Crossref] [PubMed][Google Scholar]

02. WHO. Global tuberculosis report- the burden of disease caused by TB. WHO/HTM/TB/2013,11, Geneva, Switzerland- World Health Organization. 2013. [Crossref][PubMed][Google Scholar]

03. WHO. Global tuberculosis control- WHO report 2016, report. Geneva- World Health Organization. 2016. [Crossref][PubMed][Google Scholar]

04. George EL, Iype T, Cherian A, Chandy S, Kumar A, Balakrishnan A, Vijayakumar K. Predictors of mortality in patients with meningeal tuberculosis. Neurol India. 2012;60(1)18-22. doi: 10.4103/00283886.93583 [Crossref][PubMed][Google Scholar]

05. Misra UK, Kalita J, Srivastava M, Mandal SK. Prognosis of tuberculous meningitis- a multivariate analysis. J Neurol Sci. 1996 Apr;137(1)57-61. doi: 10.1016/0022-510x(95)00334-x

[Crossref]

[PubMed][Google Scholar]

06. Thwaites GE, Tran TH. Tuberculous meningitismany questions, too few answers. Lancet Neurol. 2005;4(3)160-70. doi: 10.1016/S1474-4422(05) 01013-6 [Crossref][PubMed][Google Scholar]
07. Chakraborty A K. "Estimating mortality from tuberculous meningitis in a community- use of available epidemiological parameters in the Indian context. Indian Journal of Tuberculosis. 2000;47 (1)9-13. [Crossref][PubMed][Google Scholar]

08. Thwaites GE, Nguyen DB, Nguyen HD, Hoang TQ, Do TT, Nguyen TC, et al. Dexamethasone for the treatment of tuberculous meningitis in adolescents and adults. N Engl J Med. 2004 Oct 21;351(17)1741-51. doi: 10.1056/NEJMoa040573 [Crossref][PubMed][Google Scholar]

09. Kalita J, Misra UK, Ranjan P. Predictors of longterm neurological sequelae of tuberculous meningitis- a multivariate analysis. Eur J Neurol. 2007;14(1)33-7. doi: 10.1111/j.1468-1331.2006. 01534.x [Crossref][PubMed][Google Scholar]

10. IBM Corp. Released 2013. IBM SPSS Statistics for Windows, Version 22. 0. Armonk, NY: IBM Corp [Crossref][PubMed][Google Scholar]

11. Cherian A, Thomas SV. Central nervous system tuberculosis. Afr Health Sci. 2011 Mar;11(1)116-27. [Crossref][PubMed][Google Scholar]

12. Verdon $R$, Chevret $S$, Laissy JP, Wolff $M$. Tuberculous meningitis in adults- review of 48 cases. Clin Infect Dis. 1996;22(6)982-8. doi: 10.1093/clinids/22.6.982 [Crossref][PubMed] [Google Scholar]

13. Kent SJ, Crowe SM, Yung A, Lucas CR, Mijch AM. Tuberculous meningitis- a 30-year review. Clin Infect Dis. 1993;17(6)987-94. doi: 10.1093/clinids/ 17.6.987 [Crossref][PubMed][Google Scholar]

14. A R Rich, H A McCordock. The pathogenesis of tuberculous meningitis. Bulletin of the Johns Hopkins Hospital. 1933;52;5-37. [Crossref] [PubMed][Google Scholar]

15. Hsu PC, Yang CC, Ye JJ, Huang PY, Chiang PC, Lee $\mathrm{MH}$. Prognostic factors of tuberculous meningitis in adults- a 6-year retrospective study at a tertiary hospital in northern Taiwan. J Microbiol Immunol Infect. $2010 \mathrm{Apr} ; 43(2) 111-8$. doi: 10.1016/S16841182(10)60018-7 [Crossref][PubMed][Google Scholar]

16. Katti MK. Immunodiagnosis of tuberculous meningitis- rapid detection of mycobacterial antigens in cerebrospinal fluid by reverse passive hemagglutination assay and their characterization by Western blotting. FEMS Immunol Med Microbiol. 2001;31(1)59-64. doi: 10.1111/j.1574-695X.2001. tb01587.x [Crossref]「PubMed]/Gooqle Scholar] 
17. Luo $M$, Wang $W$, Zeng $Q$, Luo $Y$, Yang $H$, Yang $X$. Tuberculous meningitis diagnosis and treatment in adults- A series of 189 suspected cases. Exp Ther Med. 2018 Sep;16(3)2770-2776. doi: 10.3892/etm.2018.6496 [Crossref][PubMed][Google Scholar]

18. Garcia-Monco JC. Central nervous system tuberculosis. Neurol Clin. 1999 Nov;17(4)737-59. doi: 10.1016/s0733-8619(05)70164-x [Crossref] [PubMed][Google Scholar]

19. Kalita J, Misra UK. Outcome of tuberculous meningitis at 6 and 12 months- a multiple regression analysis. Int J Tuberc Lung Dis. 1999 Mar;3(3)261-5. [Crossref][PubMed][Google Scholar]

20. Hosoglu S, Geyik MF, Balik I, Aygen B, Erol S, Aygencel TG, et al. Predictors of outcome in patients with tuberculous meningitis. Int J Tuberc Lung Dis. 2002 Jan;6(1)64-70. [Crossref][PubMed][Google Scholar]

21. Misra UK, Kalita J, Roy AK, Mandal SK, Srivastava M. Role of clinical, radiological, and neurophysiological changes in predicting the outcome of tuberculous meningitis- a multivariable analysis. J Neurol Neurosurg Psychiatry. 2000 Mar;68(3)300-3. doi: 10.1136/jnnp.68.3.300 [Crossref][PubMed][Google Scholar]

22. Hsieh FY, Chia LG, Shen WC. Locations of cerebral infarctions in tuberculous meningitis. Neuroradiology. 1992;34(3)197-9. doi: 10.1007/BF00596334 [Crossref][PubMed][Google Scholar]
23. Girgis NI, Sultan Y, Farid Z, Mansour MM, Erian MW, Hanna LS, et al. Tuberculosis meningitis, Abbassia Fever Hospital-Naval Medical Research Unit No 3-Cairo, Egypt, from 1976 to 1996. Am J Trop Med Hyg. 1998 Jan;58(1)28-34. doi: 10.4269/ajtmh.1998.58.28 [Crossref][PubMed] [Google Scholar]

24. Rock RB, Hu S, Gekker G, Sheng WS, May B, Kapur V, Peterson PK. Mycobacterium tuberculosisinduced cytokine and chemokine expression by human microglia and astrocytes- effects of dexamethasone. J Infect Dis. 2005 Dec 15;192(12)2054-8. doi: 10.1086/498165 [Crossref] [PubMed][Google Scholar]

25. Bidstrup $C$, Andersen $\mathrm{PH}$, Skinhøj $\mathrm{P}$, Andersen $A B$. Tuberculous meningitis in a country with a low incidence of tuberculosis- still a serious disease and a diagnostic challenge. Scand J Infect Dis. 2002;34(11)811-4. doi: 10.1080/0036554021000026938 [PubMed][Google Scholar]

[Crossref]

26. van Well GT, Paes BF, Terwee $C B$, Springer $P$, Roord JJ, Donald PR, et al. Twenty years of pediatric tuberculous meningitis- a retrospective cohort study in the western cape of South Africa. Pediatrics. 2009;123(1)e1-8. doi: 10.1542/peds.2008-1353 [Crossref][PubMed][Google Scholar] 